\title{
Clinical aspects of acute pneumonia in Bihor county
}

\author{
Andrei Csep \\ From The 10th Edition of the Scientific Days of the National Institute for Infectious Diseases "Prof Dr Matei \\ Bals" \\ Bucharest, Romania. 15-17 October 2014
}

\section{Background}

In developing countries, acute pneumonia is a very important public health problem.

\section{Methods}

Our goal was to study all the 420 patients with acute pneumonia who were admitted to the Infectious Clinic in Oradea between 01.01.2013-31.12.2013. The diagnosis was performed based on clinical, biological and radiological criteria.

\section{Results}

Most of the patients came from rural area (60\%). 55\% of them were female and $45 \%$ were male. We had 3 groups of acute pneumonia: lobar pneumonia (39\%), interstitial pneumonia (47\%) and bronchopneumonia (14\%). More than half of the patients had bacterial pneumonia (70\%). From these, $68 \%$ had unknown etiology. The most affected ranges were the age group 51-55 and 61-65. Most cases of acute pneumonia were diagnosed in autumn. Associated pathology was observed in old patients (47\%)

\section{Conclusion}

The most exposed category of age was represented by adults between 51 and 55 years and 61 and 65 years old.

Published: 15 October 2014

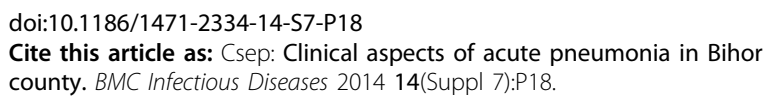

Submit your next manuscript to BioMed Central and take full advantage of:

- Convenient online submission

- Thorough peer review

- No space constraints or color figure charges

- Immediate publication on acceptance

- Inclusion in PubMed, CAS, Scopus and Google Scholar

- Research which is freely available for redistribution 